УДК 351:339.543

DOI https://doi.org/10.37687/2413-6433.2020-2.4

\author{
Драган О.В., \\ доктор юридичних наук, доцент \\ Університету державної фіскальної служби України \\ ORCID: 0000-0002-5696-6360
}

\begin{abstract}
ЩОДО ВІДПОВІДАЛЬНОСТІ ПЛАТНИКІВ ПОДАТКІВ
ЗА НЕДОПУСК ПОСАДОВИХ ОСІБ МИТНОГО ОРГАНУ ДО ПРОВЕДЕННЯ ПЕРЕВІРКИ: ЗАРУБІЖНИЙ ДОСВІД
\end{abstract}

\title{
ON THE TAXPAYERS' RESPONSIBILITY FOR NON-ADMISSION OF THE CUSTOMS OFFICIALS TO CARRY OUT THE INSPECTION: FOREIGN EXPERIENCE
}

\begin{abstract}
У статті здійснено аналіз зарубіжного досвіду інших країн щодо відповідальності платників податків за недопуск посадових осіб митного органу до проведення перевірки. При цьому особлива увага приділена розміру штрафних санкцій, які можуть бути застосовані до платників податків. За результатами проведеного аналізу зроблено висновки, що економічні важелі впливу є найбільш ефективними стосовно платників податків, які не допускають посадових осіб митного органу до проведення перевірки. Автором також обгрунтовуються пропозиції щодо необхідності внесення змін до Митного Кодексу України в напрямі збільшення розміру штрафних санкцій та їх диференціації на основі періодичності. Зокрема акцентовано, що в разі збільшення розмірів штрафів варто враховувати, що адміністративні-обмежувальні заходи (санкції) будуть надзвичайно чутливими для тих суб'єктів господарювання, які здійснюють свою діяльність на постійній основі, щоденно оформлюючи вантажі на митниці. Для суб' єктів із разовою чи нерегулярною зовнішньоекономічною діяльністю застосування адміністративно-фінансових санкцій, зокрема штрафів, буде більш дієвим, ніж застосування адміністративно-обмежувальних заходів (санкцій) (за винятком арешту активів). На підприємства $з$ невеликим господарським товарооборотом суттєво впливатимуть ті адміністративно-обмежувальні заходи (санкції), які «вимиватимуть» їхні оборотні кошти. Проте найбільшого ефекту можна буде досягти на основі комплексного (одночасного) використання адміністративно-обмежувальних та адміністративно-фінансових заходів (санкцій) юридичної відповідальності до порушників митного законодавства.
\end{abstract}

Ключові слова: перевірка, платники податків, митний орган, юридична відповідальність, итрафні санкиї.

The article analyzes the foreign experience of other countries on the taxpayers' responsibility for not allowing customs officials to conduct the inspection. At the same time, special attention is paid to the size of penalties that can be applied to taxpayers. Based on the results of the analysis carried out, it was concluded that the economic levers of influence are the most effective for taxpayers who do not allow customs officials to conduct an audit. The author also substantiates the proposals on the need to amend the Customs Code of Ukraine in the direction of increasing the size of penalties and their differentiation on the regular basis. The article analyzes the foreign experience of other countries on the taxpayers' responsibility for not allowing customs officials to conduct the inspection. At the same time, special attention is paid to the size of penalties that can be applied to taxpayers. Based on the results of the analysis carried out, it was concluded that the economic levers of influence are the most effective for taxpayers who do not allow customs officials to conduct an audit. The author also substantiates the proposals on the need to amend the Customs Code of Ukraine in the direction of increasing the size of penalties and their differentiation on the regular basis. Additionally, it is emphasized that when increasing the size of fines, it should be taken into account that administrative restrictive measures (sanctions) will be extremely sensitive for those businesses who processing their cargo at customs on a daily basis and operate on a permanent basis. For entities with one-time or irregular foreign economic activity, the application of administrative and financial sanctions, in particular fines, will be more effective than the application of administrative and restrictive measures (sanctions) (except for the seizure of assets). For businesses with a small economic turnover, those administrative and restrictive measures (sanctions) that will "wash away" their working capital will have a significant impact. However, the greatest effect can be achieved on the basis of comprehensive (simultaneous) use of administrative restrictive and financial measures (sanctions) to violators of customs legislation.

Key words: inspection, taxpayers, customs body, legal responsibility, penalties. 
У Комітеті Верховної Ради України з питань фінансів, податкової та митної політики розробляється проект Закону про внесення змін до Митного кодексу України стосовно проведення документальних перевірок дотримання вимог законодавства України з урахуванням положень міжнародних договорів, згода на обов'язковість яких надана Верховною Радою України, та міжнародної практики.

Голова Комітету звернувся до Університету державної фріскальної служби України (далі Університет) з проханням надати відповідні пропозиції, спираючись у тому числі на практику застосування таких норм іншими країнами.

Працівниками Науково-дослідного центру митної справи Університету державної фріскальної служби України на підставі практики застосування таких норм іншими країнами, були висловлені певні міркування з приводу проблематики, порушеної у зверненні.

Ні в кого не викликає сумніву той фракт, що митні платежі призначені для поповнення дохідної частини Державного бюджету України. Митні органи зобов'язані це поповнення забезпечити.

Особливу значущість у цьому контексті мають документальні перевірки додержання вимог законодавства України з питань митної справи, в тому числі своєчасності, достовірності, повноти нарахування та сплати митних платежів, і особливо такий їх вид, як документальні позапланові виїзні перевірки. Адже вони, з позиції Державної митної служби України, являють собою один із найбільш впливових важелів, а з позиції платників митних платежів $є$ ефективним інструментом тиску на бізнес.

Проблематика проведення таких перевірок, а особливо питання допуску працівників контролюючого органу до їх проведення не перестає привертати увагу науковців.

В Україні за недопуск платником податків посадових осіб митного органу до проведення виїзної перевірки за місцем проведення перевірки, ненадання платником податків необхідних документів чи невиконання їх законних вимог у рамках проведення документальної перевірки передбачається адміністративна відповідальність [2, с. 558].

Через інститут адміністративної відповідальності реалізуються норми різних галузей права, в тому числі і митного, тому коло актів, які її стосуються, досить широке. Центральне місце серед них займає Кодекс України про адміністративні правопорушення [4]. Проте в цьому випадку нормативно-правовим актом, яким встановлена юридична відповідальність за «недопуск платником податків посадових осіб митного органу», $€$ Митний кодекс України [7].

В основу адміністративно-фрінансових заходів (санкцій) юридичної відповідальності суб'єктів ЗЕД покладено принцип застосування до порушника митного законодавства штрафнних санкцій.
В Україні це питання врегульоване Митним кодексом, а саме ч. 2 ст. 474 МК: вчинення правопорушення, передбаченого ч. 1 цієї статті, особою, яка протягом року притягалася до відповідальності за вчинення такого правопорушення, а так само перешкоджання посадовій особі митного органу, невиконання її вимог під час проведення перевірки обліку товарів, що переміщуються через митний кордон України та/або перебувають під митним контролем, чи документальної перевірки дотримання вимог законодавства України з питань митної справи, тягнуть за собою накладення штрафу в розмірі п'ятисот неоподатковуваних мінімумів доходів громадян [7] (8,5 тис. грн).

Для порівняння, Грузія нещодавно значно посилила відповідальність за такі делікти, ввівши їх до складу митних правопорушень (ст.ст. 177-178) Митного кодексу Грузії від 28.06.2019 p. № 4905-Ill [9]:

Ст. 177. Опір уповноваженій особі митного органу, ігнорування його законних вимог.

1. Опір уповноваженій особі митного органу, ігнорування його законних вимог, які спричинили затримку здійснення заходів, передбачених митним законодавством Грузії, тягнуть за собою накладення штрафуу в розмірі 800 ларі $(6,8$ тис. грн1).

2. Діяння, передбачені ч. 1 цієї статті, вчинені повторно, тягнуть за собою накладення штрафу в розмірі 2000 ларі (17 тис. грн).

Ст. 178. Ненадання інфрормації митному органу.

1. У разі вимоги митного органу ненадання митному органу в термін, встановлений митним законодавством Грузії, інфоормації, пов'язаної із здійсненням митного нагляду, митного контролю або митних формальностей, тягне за собою накладення штрафу в розмірі 400 ларі (3,4 тис. грн).

2. Діяння, передбачене ч. 1 цієї статті, вчинене повторно, тягне за собою накладення штрафру в розмірі 1000 ларі (8,5 тис. грн).

3. Неподання митному органу в установленому порядку особою, що здійснює міжнародні повітряні перевезення, попередньої інфрормації про транспортний засіб, що здійснює міжнародні повітряні перевезення, товари або (i) пасажирів, які підлягають переміщенню зазначеним транспортним засобом, тягне за собою накладення штрафру в розмірі 2000 ларі (17 тис. грн).

4. Діяння, передбачене ч. 3 цієї статті, вчинене повторно, тягне за собою накладення штрафру в розмірі 4000 ларі (34 тис. грн).

В Азербайджанській Республіці, відповідно до ст. 276 Кодексу Азербайджанської Республіки про адміністративні проступки від 11.07.2000 р. № 906-IQ [5], перешкоджання доступу посадової особи відповідного органу виконавчої влади Азербайджанської Республіки в порядку, вста-

\footnotetext{
Тут і далі сума визначена за валютним курсом на березень 2020 р.
} 
новленому законодавством, на територію або у приміщення, де можуть знаходитися товари і транспортні засоби, що підлягають митному контролю, документи, необхідні для проведення такого контролю, або де здійснюється діяльність, контроль за якою покладено на відповідні органи виконавчої влади Азербайджанської Республіки, тягне за собою накладення штрафу на фрізичних осіб у розмірі від двадцяти манатів (326,60 грн) до п'ятдесяти манатів (816,5 грн), на посадових осіб - від ста манатів (163,3 грн) до ста п'ятдесяти манатів (979,8 грн).

Ст. 277 встановлює штрафні санкції за неподання відповідному органу виконавчої влади Азербайджанської Республіки звітності товари, що ввозяться, вивозяться, зберігаються, переробляються, виготовляються, купуються та реалізуються, та товари, що перебувають під митним контролем або на території вільних митних зон і вільних складів, а також недотримання порядку ведення обліку таких товарів - попередження або накладення штрафу в розмірі від ста п'ятдесяти манатів (979,8 грн) до двохсот п'ятдесяти манатів (1233,1 грн).

Як альтернативний спосіб досягнення вищенаведених цілей посилення відповідальності суб'єктів господарювання, вартим уваги є досвід країн Євразійського економічного союзу. Наднаціональним митним регулюванням, визначеним у Митному кодексі ЄAEC [10], встановлено наведене нижче (ст. 133):

У разі необґрунтованої відмови особи, що перевіряється, забезпечити доступ посадових осіб митних органів на об'єкт особи, що перевіряється, вони мають право входити на цей об'єкт із припиненням опору і розкриттям замкнених приміщень у присутності 2 (двох) понятих, за винятком випадків, якщо законодавством держав-членів Митного союзу встановлений інший порядок доступу посадових осіб державних органів на окремі об'єкти. Про всі випадки входження на об'єкти осіб, що перевіряються, 3 припиненням опору і розкриттям замкнених приміщень митні органи повідомляють прокурора протягом 24 (двадцяти чотирьох) годин.
У Казахстані, відповідно до п. 6 ст. 417 Кодексу Республіки Казахстан «Про митне регулювання в Республіці Казахстан» від 26.12.2017 р. № 123VI [6], у разі неподання при камеральній митній перевірці особою, яка перевіряється, на вимогу документів, заявлених у митній декларації, відомості, заявлені у митній декларації на підставі таких документів, вважаються недостовірно заявленими.

Враховуючи, що штрафні санкції, передбачені митним законодавством України виконують як превентивну, так і каральну функції та з врахуванням досвіду Грузії, яка нині є однією із лідерів у питаннях реформування митної сфери не лише на пострадянському просторі, але й на світовому рівні, Комітету рекомендовано переглянути розмір штрафрів у сторону їх збільшення.

Разом із тим акцентовано, що в разі збільшення розмірів штрафі варто враховувати, що адміністративні-обмежувальні заходи (санкції) будуть надзвичайно чутливими для тих суб'єктів господарювання, які здійснюють свою діяльність на постійній основі, щоденно оформлюючи вантажі на митниці. Для суб'єктів із разовою чи нерегулярною зовнішньоекономічною діяльністю застосування адміністративно-фрінансових санкцій, зокрема штрафів, буде більш дієвим, ніж застосування адміністративно-обмежувальних заходів (санкцій) (за винятком арешту активів). На підприємства із невеликим господарським товарооборотом суттєво впливатимуть ті адміністративно-обмежувальні заходи (санкції), які «вимиватимуть» їхні оборотні кошти. Проте найбільшого ефекту можна буде досягти на основі комплексного (одночасного) використання адміністративно-обмежувальних та адміністративно-фінансових заходів (санкцій) юридичної відповідальності до порушників митного законодавства.

Підсумовуючи викладене, зауважимо, що санкції за порушення митних правил мають бути встановлені такі, які виключають їхній дискримінаційний характер і створюють правові можливості для забезпечення правопорядку в нашій державі.

\section{Список використаних джерел:}

1. Венгеров А.Б. Теория государства и права : учебник для юридических вузов. Москва : Новый Юрист, 1998. $650 \mathrm{c}$.

2. Господарський кодекс України від 16.01.2003 р. № 436-IV. Відомості Верховної Ради Украӥни (ВВР). 2003. № 18. № 19-20. № 21-22. Ст. 144

3. Кодекс України про адміністративні правопорушення від 07.12.1984 р. № 8073-Х. Відомості Верховноі Ради Украӥнської РСР (ВВР). 1984. Додаток до № 51. Ст. 1122.

4. Кодекс Азербайджанской Республики об административных проступках от 11.07.2000 г. № 906-IQ. URL: http://continent-online.com/Document/?doc_id=36865427 (дата звернення: 25.04.2020)

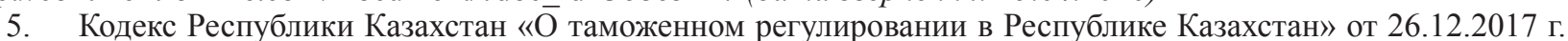
№ 123-VI. URL: https://online.zakon.kz/document/?doc_id=39082703 (дата звернення: 25.04.2020)

6. Митний кодекс України від 13.03.2012 р. №- 4495-VI. Відомості Верховної Ради Украӥни (ВВР). 2012. № 44-45. № 46-47. № 48. Ст. 552 
7. Про рішення Ради національної безпеки і оборони України від 19 березня 2019 року «Про застосування, скасування та внесення змін до персональних спеціальних економічних та інших обмежувальних заходів (санкцій)» : Указ Президента України від 19.03.2019 p. № 82/2019. URL: https://zakon.rada.gov.ua/laws/ show/82/2019 (дата звернення: 25.04.2020)

8. Таможенный кодекс Грузии от 28.06.2019 г. № 4905-IIb. URL: https://matsne.gov.ge/ru/document/ view/4598501?publication=0 (дата звернення: 25.04.2020)

9. Таможенный кодекс Евразийского экономического союза (приложение № 1 к Договору о Таможенном кодексе Евразийского экономического союза). URL: http://www.consultant.ru/document/cons_doc_LAW_215315/ (дата звернення: 25.04.2020) 